\title{
Identification, Quantification, and Antioxidant Activity of Hydroalcoholic Extract of Artemisia campestris from Algeria
}

\author{
Cezayir'de Yetişen Artemisia campestris'in Sulu Alkollü Ekstresinin \\ Tanımlanması, Kantitasyonu ve Antioksidan Aktivitesi
}

\author{
(D) Boulanouar BAKCHICHE1* ${ }^{*}$ (D) Abdelaziz GHERIB1, (D) Maria Rosário BRONZE2 ${ }^{2}$ (D) Mosad A. GHAREEB³ \\ 1Amar Telidji University, Faculty of Technology, Laboratory of Process Engineering, Laghouat, Algeria \\ 2University of Lisbon, Faculty of Pharmacy, Lisboa, Portugal \\ 3Medicinal Chemistry Department, Theodor Bilharz Research Institute, Kornaish El-Nile, Warrak El-Hadar, Imbaba, Giza, Egypt
}

\begin{abstract}
Objectives: Our study aimed to investigate the chemical profile of hydroalcoholic extract of Algerian Artemisia campestris and its antioxidant activity. Materials and Methods: The hydroalcoholic extract of Algerian A. campestris was investigated for its phenolic constituents using high performance liquid chromatography (HPLC)-diode array detection (DAD)-electrospray ionization (ESI)-mass spectrometer (MS)/MS. The in vitro antioxidant activity and total phenolic content were also evaluated via oxygen radical absorbance capacity and Folin-Ciocalteu assays, respectively.

Results: HPLC-DAD-ESI-MS/MS analysis revealed that the main tentatively identified compounds were caffeoylquinic acid isomers, flavonoids, and benzoic acid derivatives. Additionally, the hydroalcoholic extract exhibited a promising antioxidant activity value of $120.5 \pm 10.4 \mu m o l$ Trolox equivalent antioxidant capacity/g dry weight (DW), and a strong correlation exists between this activity and the total phenolic content value of $102.09 \pm 1.65 \mathrm{mg} / \mathrm{g}$ gallic acid equivalents DW.
\end{abstract}

Conclusion: The hydroalcoholic extract of $A$. campestris is a promising candidate for the production of naturally occurring antioxidant agents.

Key words: Artemisia campestris, polyphenols, flavonoids, chlorogenic acid, antioxidant

öz

Amaç: Bu çalışmada, Cezayir'de yetișen Artemisia campestris'in sulu alkollü ekstresinin kimyasal profilinin ve antioksidan etkisinin araştırılması amaçlanmıştır.

Gereç ve Yöntemler: Cezayir'de yetişen A. campestris'in sulu alkollü ekstresinin fenolik bileșenleri yüksek performanslı sıvı kromatografisi (HPLC) diyot dizinli dedektör-(DAD)-elektrosprey iyonizasyonu (ESI)-mass spektrometresi (MS)/MS kullanılarak incelenmiştir. In vitro antioksidan aktivite ve toplam fenolik içerik de sırasıyla oksijen radikal absorbans kapasitesi ve Folin-Ciocalteu analizleri ile değerlendirilmiştir.

Bulgular: HPLC-DAD-ESI-MS/MS analizi, esas olarak saptanan ana bileşiklerin, kafeoilkuinik asit izomerleri, flavonoitler ve benzoik asit türevleri

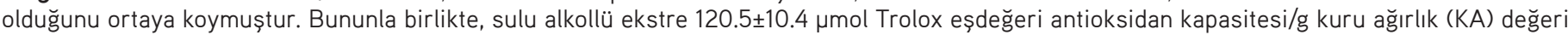
ile önemli derecede antioksidan aktivite göstermiş ve bu aktivite ile $102.09 \pm 1.65 \mathrm{mg} / \mathrm{g}$ gallik asit eş değeri KA olduğu belirlenen toplam fenolik içerik değeri arasında güçlü bir korelasyon saptanmıștır.

Sonuç: Sonuç olarak, A. campestris'in sulu alkollü ekstresinin, doğal antioksidan ajanların üretimi için umut verici bir aday olduğu belirtilmiştir. Anahtar kelimeler: Artemisia campestris, polifenoller, flavonoitler, klorojenik asit, antioksidan

*Correspondence: E-mail: b.bakchiche@lagh-univ.dz, Phone: 00213662174441 ORCID-ID: orcid.org/0000-0002-3124-5153

Received: 01.02 .2018 , Accepted: 25.04 .2018

๑Turk J Pharm Sci, Published by Galenos Publishing House. 


\section{INTRODUCTION}

The genus Artemisia is one of the largest and most widely distributed genera of the family Asteraceae in Europe and North Africa, and its species have been characterized for their pronounced biological activities and are considered to produce most medicinally important secondary metabolites. Eleven species of Artemisia can be found in the Algerian flora. ${ }^{12}$ Artemisia campestris is a perennial faintly aromatic herb widespread in the south of Algeria, commonly known as "dgouft". The aerial parts of the plant have been used in traditional medicine as a febrifuge, vermifuge, and anticancer agent and to treat digestive troubles, gastric ulcer, and menstrual pain. ${ }^{3-5}$ A. campestris extract was reported to be a potent free radical scavenger of 2,2'-diphenyl-1-picryl hydrazyl, 2,2'-azinobis3ethylbenzthiazoline-6-sulfonic acid (ABTS ${ }^{*}$ ), and superoxide anion radicals $\left(\mathrm{O}_{2}^{-*}\right)$ but there is a lack of knowledge regarding the phenolic composition of this plant and its relation with its antioxidant properties, since only a few studies have identified a small number of phenolic compounds. ${ }^{5-8}$

However, the phenolic profile of $A$. campestris is quite complex. Flavonoids present in this species consist of flavones, flavonols, flavanones, dihydroflavonols, and their methyl ethers, whereas the isolation of coumarins and phloracetophenones is also reported. ${ }^{910}$ Chlorogenic acid is a natural product occurring in a large number of different plants or parts of the plant; for example, in A. campestris chemically it is the ester of caffeic acid and quinic acid, 3-O-caffeoylquinic acid. Other isomers are derivative chlorogenic acid 4-O-caffeoylquinic acid and 5-O-caffeoylquinic acid. Additionally, there are other isomers, called iso-chlorogenic acids, with two caffeic acid moieties such as 3,4-dicaffeoylquinic acid, 4,5-dicaffeoylquinic acid, and 1,5-dicaffeoylquinic acid.

The objective of the present work was to contribute to the identification of the major phenolic compounds in the hydroalcoholic extract of $A$. campestris by high-performance liquid chromatographic/diode array detector (HPLC-DAD) coupled with electrospray ionization/mass spectrometry (ESI-MS). In addition, HPLC-DAD-electrochemical detector quantification of phenolic and flavonoid contents and hydroxycinnamic acid was carried out. Finally, the antioxidant capacity of the extract was also evaluated by oxygen radical absorbance capacity (ORAC) assay.

\section{EXPERIMENTS}

\section{Chemicals}

Chlorogenic acid was purchased from Extrasynthese (Genay, France). Methanol for HPLC-GOLD-Ultra gradient was purchased from Carlo Erba Reagents (Val de Reuil, France). Phosphoric acid (85\%) and formic acid (98\%) were purchased from Panreac Química (Barcelona, Spain) Acetonitrile HPLC gradient grade was purchased from VWR ${ }^{\circledR}$ (Leuven, Belgium). Milli- ${ }^{\circledR}$ water (18.2 M .. $\left.\mathrm{cm}\right)$ was obtained in a Millipore-Direct Q3 ultraviolet (UV) System (Molsheim, France).

\section{Plant material}

Aerial parts of $A$. campestris were collected from the Laghouat region in the northern Algerian Sahara in summer 2015. The identification and authentication of the plant were carried out by Dr. Mohamed Kouidri, botanist (Department of Agronomy, Faculty of Sciences, University of Laghouat, Algeria) and the voucher specimens were deposited at the Laboratory of Process Engineering, University of Laghouat (number LGP Ac/08/15).

\section{Preparation of the hydroalcoholic extract}

One gram of dried powder was mixed with ethanol:water (8:2; $\mathrm{v} / \mathrm{v}, 10 \mathrm{~mL}$ ) and macerated under sonication, (water bath, room temperature, $30 \mathrm{~min}$ ). The material was filtered and the crude extract obtained was analyzed directly by HPLC. The procedure was performed in triplicate.

\section{Equipment and conditions of analysis}

Liquid chromatography with diode array and electrochemical detection

The HPLC system used was a Thermo Finnigan (Surveyor, San Jose, CA, USA), equipped with an autosampler, pump, photodiode-array detector (PDA), and electrochemical detector (ED). Chromatographic separation of compounds was carried out on a Lichrocart RP-18 column $(250 \times 4 \mathrm{~mm}$, particle size 5 $\mu \mathrm{m}$, Merck). The Dionex ${ }^{\circledR}$ ED performed signal measurements by integrated voltammetry at potentials between $-1.0 \mathrm{~V}$ and $1.0 \mathrm{~V}$ with a scan time of $1.00 \mathrm{~s}$. The obtained results were acquired at a frequency of $50 \mathrm{~Hz}$ using an analogue/digital converter. The photodiode array detector was programmed for scanning between 192 and $798 \mathrm{~nm}$ at a speed of $1 \mathrm{~Hz}$ with a bandwidth of $5 \mathrm{~nm}$. The detection was monitored using three individual channels, 280, 320, and $360 \mathrm{~nm}$, at a speed of $10 \mathrm{~Hz}$ with a bandwidth of $11 \mathrm{~nm}$. The injection volume was $20.00 \mu \mathrm{L}$ and total time of analysis was $120 \mathrm{~min}$. A binary gradient elution (Table 1) was used. The mobile phase was as follows: $0.5 \%$ formic acid in Milli- ${ }^{\circledR}$ Water $95 \%$ (eluent $A$ ) and $0.5 \%$ phosphoric acid in acetonitrile $90 \%$ and $9.5 \%$ Milli- $Q^{\circledR}$ Water (eluent B). The flow rate was systematically controlled and set at $0.3 \mathrm{~mL} / \mathrm{min}$.

\section{Liquid chromatography with mass spectrometry}

The identification of compounds in the extracts was carried out by HPLC-MS/MS using Waters ${ }^{\circledR}$ Alliance 2695 HPLC equipment fitted with a DAD, Waters 2996 (PDA), and a triple quadrupole spectrometer (TQ) (Micromass ${ }^{\circledR}$ Quattro micro ${ }^{\mathrm{TM}}$, Waters) with an ESI source operating in negative mode. The capillary in the ESI source was placed at $3.0 \mathrm{kV}$ and the cone at $30 \mathrm{~V}$. The chromatographic separation was performed on a LiChroCART RP-18 column ( $250 \times 4 \mathrm{~mm}$, particularly from size $5 \mu \mathrm{m}$, Merck) at $35^{\circ} \mathrm{C}$. The eluents used were $A$ : formic acid $(0.5 \% \mathrm{v} / \mathrm{v})$ and B: acetonitrile (LC-MS grade). A gradient elution program was applied for chromatographic analysis (Table 1). Flow rate was maintained at $0.3 \mathrm{~mL} / \mathrm{min}$ and the injection volume was $10 \mu \mathrm{L}$. Ultrapure nitrogen $\left(\mathrm{N}_{2}\right)$ was used as nebulizer and drying gas and gas. Ultrapure argon was used as the collision gas at a 
pressure of $10^{-4}$ mbar. For data acquisition and treatment of data MassLynx ${ }^{\circledR}$ software version 4.1 was used.

\section{Determination of phenolic chromatographic profile}

Total phenolic content was determined using the $280 \mathrm{~nm}$ total peak area above $40 \mathrm{~min}$. Calibration curves with gallic acid (0$25 \mathrm{ppm}$ ) were created and the final results were expressed in terms of gallic acid equivalents (GAE) per gram of dry weight (DW) (mg/g GAE DW).

Total flavonoids content was determined using the $360 \mathrm{~nm}$ total peak area above $40 \mathrm{~min}$. Calibration curves with rutin (0$50 \mathrm{ppm}$ ) were created and the final results were expressed in terms of rutin equivalents (RE) per gram of DW (mg/g RE DW).

Total hydroxycinnamic acids content was determined using the $320 \mathrm{~nm}$ total peak area between 20 and $40 \mathrm{~min}$. Calibration curves with caffeic acid (0-25 ppm) were created and the final results were expressed in terms of caffeic acid (CA) equivalents per gram of DW (mg/g CA DW). Additionally, the

Table 1. Gradient eluents used for analysis by HPLC-DAD-ED

\begin{tabular}{lll} 
Time $(\mathrm{min})$ & Eluent A (\%) & Eluent B (\%) \\
\hline 0.10 & 98.90 & 1.10 \\
\hline 15 & 91.00 & 9.00 \\
\hline 20 & 87.80 & 12.20 \\
\hline 30 & 87.80 & 12.20 \\
\hline 55 & 86.50 & 13.50 \\
\hline 95 & 73.00 & 27.00 \\
\hline 105 & 37.00 & 63.00 \\
\hline 110 & 37.00 & 63.00 \\
\hline 125 & 98.90 & 1.10 \\
\hline 130 & 98.90 & 1.10 \\
\hline
\end{tabular}

HPLC: High performance liquid chromatography, DAD: Diode array detection, ED: Electrochemical detector content of total phenols was determined colorimetrically with Folin's reagent according to the method reported by Stamatakis et al. ${ }^{11}$ The phenolic contents were expressed as $\mathrm{mg}$ of GAE per gram of DW (mg/g GAE DW).

\section{ORAC}

Peroxyl radical scavenging capacity was determined by the ORAC method. The assay was carried out by following the method reported by Huang et al. ${ }^{12}$ modified for the FL800 microplate reader (BioTek Instruments, Winooski, VT, USA) as described by Feliciano et al.13 All data were expressed as micromoles of Trolox equivalent antioxidant capacity (TEAC) per gram DW ( $\mu$ mol TEAC/g DW).

\section{RESULTS}

The HPLC method employed for the separation of phenolic components in the hydroalcoholic extract of $A$. campestris revealed a good separation of the majority of the compounds. Chromatograms at $280 \mathrm{~nm}$ are widely used to study phenolic compounds because absorption at this wavelength is suitable to detect a large number of such compounds. The maximum absorption wavelengths $\left(\lambda_{\max }\right)$, and parent, aglycone, and fragment ion masses of the components detected in the aqueous extract of $A$. campestris are shown in Table 2, where the compounds are numbered according to their retention times $\left(R_{t}\right)$ in the obtained chromatograms.

Four compounds were unequivocally identified based on the analysis of standard compounds and comparing their HPLC retention time, UV spectra, and MS/MS fragmentation pattern. The remaining compounds were characterized and their structures proposed based mainly on the MS/MS fragmentation data conjugated with the UV-DAD spectra. Most of the peaks showed similar UV absorptions maxima with two bands at $\lambda_{\max }$ 230-240 nm and 320-330 nm. These types of UV absorption bands are characteristic of hydroxycinnamic acids. Some peaks with characteristic UV absorptions bands for flavonoids were

\section{Table 2. Phenolic compounds tentatively identified in hydroalcoholic extract of Artemisia campestris}

\begin{tabular}{|c|c|c|c|c|c|c|}
\hline Peak no. & $R_{t}(\min )$ & Ultraviolet & {$[\mathrm{M}-\mathrm{H}]^{-} m / z$} & Fragmentations & Compounds proposed & References \\
\hline 1 & 27.5 & 259 & 153 & 141,109 & Protocatechuic acid & 19 \\
\hline 2 & 29.45 & 325 & 353 & $191,179,173$ & 5-O-Caffeoylquinic acid & 28 \\
\hline 3 & 31.6 & 266 & 205 & $143,129,114$ & Quinic acid methyl ester & 20 \\
\hline 4 & 40.26 & $224 / 326$ & 353 & $191,173,85$ & 3-O-Caffeoylquinic acid & 28 \\
\hline 5 & 44.9 & 325 & 179 & $135,107,89$ & Caffeic acid & 21 \\
\hline 6 & 58.6 & 328 & 367 & $191,173,134,93,87$ & 4-O-Feruloylquinic acid & 22 \\
\hline 7 & 73.3 & 365 & 463 & $301,179,151$ & Quercetin-O-glucoside & 23 \\
\hline 8 & 76.8 & 256 & 609 & 301 & Rutin & 24 \\
\hline 9 & 83.68 & $247 / 326$ & 515 & $353,235,191,179,173,135$ & 3,4-Dicaffeoylquinic acid & 28 \\
\hline 10 & 89.18 & $244 / 326$ & 515 & $353,191,179,173,135$ & 4,5-Dicaffeoylquinic acid & 28 \\
\hline 11 & 114.0 & & 313 & $298,283,255,163,117$ & $4^{\prime}, 7^{\prime}$-Dimethoxy luteolin & 25 \\
\hline
\end{tabular}


also detected. ${ }^{14}$ The chromatogram of the hydroalcoholic extract of the aerial parts from $A$. campestris is presented in Figure 1. The most relevant components were caffeoylquinic acids. In general, in the MS spectrum the most intense peak corresponds to the deprotonated molecular ion $[\mathrm{M}-\mathrm{H}]^{-}$. The main fragments observed in the MS/MS experiments are given in Table 2. Chemical structures of some phenolic compounds tentatively identified in hydroalcoholic extract of Artemisia campestris are given in Figure 2.

\section{Quantification of chlorogenic acid derivatives of $A$. campestris}

The content of chlorogenic acid derivatives of $A$. campestris extract was determined. The amounts of the identified compounds are given in Table 3. 3,4-Dicaffeoylquinic acid was the major caffeoylquinic acid in the hydroalcoholic extract of $A$. campestris $(274.76 \pm 9.50 \mathrm{mg}$ eq Trolox/L).

The data in Table 3 reveal the highest quantities of the three isomers of the caffeoylquinic acid (3-O-caffeoylquinic acid $191.92 \pm 5.4 \mathrm{mg}$ eq Trolox/L, 4,5-dicaffeoylquinic acid $117.61 \pm 3.52 \mathrm{mg}$ eq Trolox/L, and 5-O-caffeoylquinic acid 6.48 $\pm 0.25 \mathrm{mg}$ eq Trolox/L).

\section{Antioxidant activity and total phenolic content}

The antioxidant and total phenolic content of the $A$. campestris extract were measured by ORAC assay and the results are shown in Table 4.

$\begin{aligned} & \text { Table 3. Quantification of chlorogenic acid derivatives by } \\
& \text { electrochemical detector }\end{aligned}$
\begin{tabular}{lllll} 
Peak no. & $R_{t}$ & $\mathrm{~m} / \mathrm{z}$ & Compounds proposed & $\begin{array}{l}\mathrm{mg} \mathrm{eq} \\
\text { Trolox/L }\end{array}$ \\
\hline 2 & 29.45 & 353 & 5 -O-Caffeoylquinic acid & $6.48 \pm 0.25$ \\
\hline 4 & 40.26 & 353 & $\begin{array}{l}\text { Chlorogenic acid } \\
\text { (3-O-Caffeoylquinic acid) }\end{array}$ & $191.92 \pm 5.4$ \\
\hline 9 & 83.68 & 515 & 3,4-Dicaffeoylquinic acid & $274.76 \pm 9.50$ \\
\hline 10 & 89.18 & 515 & 4,5-Dicaffeoylquinic acid & $117.61 \pm 3.52$ \\
\hline
\end{tabular}

\section{DISCUSSION}

Characterization of caffeoylquinic acids $(M=354)$ and dicaffeoylquinic acids $(M=516)$

Two peaks were detected at $\mathrm{m} / \mathrm{z} 353$ and assigned using the hierarchical keys previously developed ${ }^{15-18}$ as wellknown chlorogenic acid (3-O-caffeoylquinic acid) and 5-O-caffeoylquinic acid. Two dicaffeoylquinic acid isomers were identified by their parent ion $\mathrm{m} / \mathrm{z} 515$ and were assigned as 3,4-dicaffeoylquinic acid and 4,5-dicaffeoylquinic acid. 8,18

\section{Characterization of other nuclei}

A peak was detected at $R_{t}=27.5 \mathrm{~min}$ with $[\mathrm{M}-\mathrm{H}]^{-}$at $\mathrm{m} / \mathrm{z} 153$ with a characteristic $\mathrm{MS}^{2}$ fragment at $\mathrm{m} / \mathrm{z} 109$ [M-H-44] due to loss of $\mathrm{CO}_{2}$ moiety; it was identified as 3,4-dihydroxybenzoic acid (protocatechuic acid). ${ }^{19}$ Another peak at $R_{t}=31.6$ min showed a deprotonated molecule $[\mathrm{M}-\mathrm{H}]^{-}$at $\mathrm{m} / \mathrm{z} 205$ with $\mathrm{MS}^{2}$ fragments of 143,129 , and 114 ; it was assigned to quinic acid methyl ester. ${ }^{20}$ A molecular ion was seen at $R_{t}=44.9$ with a deprotonated ion $[\mathrm{M}-\mathrm{H}]^{-}$at $\mathrm{m} / \mathrm{z} 179$ with daughter ions at $\mathrm{m} / \mathrm{z} 135[\mathrm{M}-\mathrm{H}-$ $44]^{-}$due to the neutral loss of $\mathrm{CO}_{2}$ moiety and 107 [M-H-4428] due to further neutral loss of CO moiety; it was identified as 3,4-dihydroxy-cinnamic acid (caffeic acid) as previously described. ${ }^{21}$ A peak at $R_{t}=58.6$ showed a deprotonated ion [M$\mathrm{H}^{-}$at $\mathrm{m} / \mathrm{z} 367$ and $\mathrm{MS}^{n}$ ions at $\mathrm{m} / z 191$ equivalent to quinic acid moiety, and another fragment at $\mathrm{m} / \mathrm{z} 173$ due to loss of $\mathrm{H}_{2} \mathrm{O}$ molecule; it was identified as 4-O-feruloylquinic acid. ${ }^{22}$ Moreover, a peak at $R_{t}=73.3$ showed a deprotonated ion [M-H] at $\mathrm{m} / z 463$ and $\mathrm{MS}^{n}$ ions at $\mathrm{m} / \mathrm{z} 301$ due to loss of glucose moiety $(-m / z 162)$ and equivalent to quercetin aglycone moiety. In addition, characteristic fragments of aglycone appeared at $\mathrm{m} / \mathrm{z} 179$ and 151 ; it was identified as quercetin- 0 -glucoside. ${ }^{23} \mathrm{~A}$ peak at $R_{t}=76.8$ showed a deprotonated ion $[\mathrm{M}-\mathrm{H}]^{-}$at $\mathrm{m} / z 609$ and a characteristic $M^{n}$ ion at $m / z 301$ due to loss of rutinosyl moiety $(-m / z 308)$ and equivalent to quercetin aglycone moiety; it was identified as quercetin-3-O-rutinoside (rutin). ${ }^{24}$ Finally,

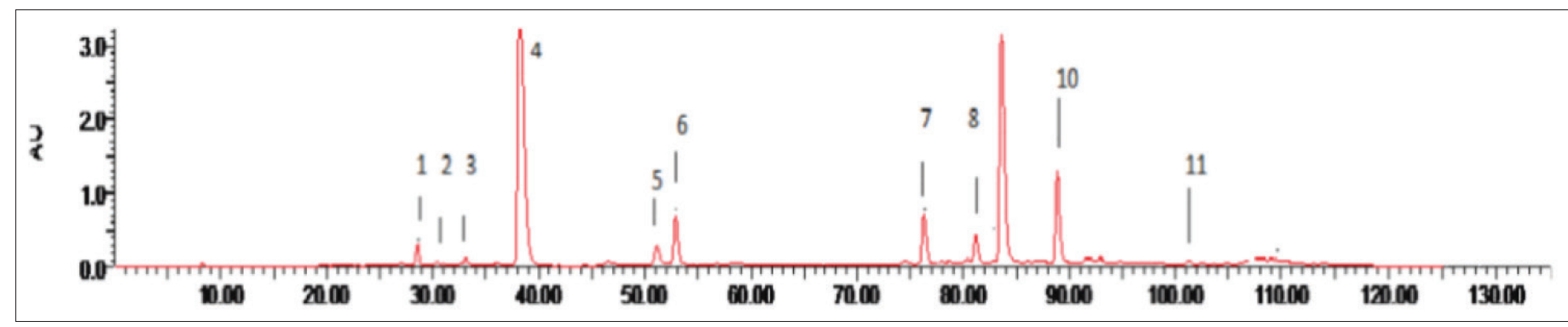

Figure 1. Chromatographic profile of Artemisia campestris obtained by HPLC-DAD at $280 \mathrm{~nm}$ HPLC: High performance liquid chromatography, DAD: Diode array detection

Table 4. Phenolic, hydroxycinnamic acid, and flavonoids contents and value of ORAC assay of Artemisia campestris extract

\begin{tabular}{llllll} 
Sample & $\begin{array}{l}\text { TPC }(280 \mathrm{~nm}) \\
\mathrm{mg} / \mathrm{g} \mathrm{DW}\end{array}$ & $\begin{array}{l}\mathrm{HAC}(320 \mathrm{~nm}) \\
\mathrm{mg} / \mathrm{g} \mathrm{CA} \mathrm{DW}\end{array}$ & $\begin{array}{l}\text { TFC }(360 \mathrm{~nm}) \\
\mathrm{mg} / \mathrm{g} \mathrm{RE} \mathrm{DW}\end{array}$ & $\begin{array}{l}\text { TPC (Folin method) } \\
(\mathrm{mg} / \mathrm{g} \text { EGA DW }\end{array}$ & $\begin{array}{l}\text { ORAC } \mu \mathrm{mol} \\
\text { TEAC/g DW) }\end{array}$ \\
\hline Artemisia campestris extract & $61.42 \pm 2.13$ & $37.26 \pm 0.88$ & $17.94 \pm 1.26$ & $102.09 \pm 1.65$ & $120.5 \pm 10.4$ \\
\hline
\end{tabular}

TPC: Total phenolic content, HAC: Hydroxycinnamic acid content, TFC: Total flavonoids content, CA: Caffeic acid, DW: Dry weight, RE: Rutin equivalents, EGA: Equivalents of gallic acid, TEAC: Trolox equivalent antioxidant capacity, ORAC: Oxygen radical absorbance capacity 
<smiles>O=C(/C=C/c1ccc(O)c(O)c1)OC1CC(O)(C(=O)O)CC(O)C1O</smiles><smiles>O=C(/C=C/c1ccc(O)c(O)c1)O[C]1C[C@](O)(C(=O)O)C[C@H](O)[C@H]1O</smiles>

3-O-Caffeoylquinic acid (Chlorogenic acid)<smiles>O=C(/C=C/c1ccc(O)c(O)c1)OC1CC(O)(C(=O)O)CC(O)C1OC(=O)/C=C/c1ccc(O)c(O)c1</smiles>
3,4-Dicaffeoylquinic acid<smiles>O=C(O)/C=C/c1ccc(O)c(O)c1</smiles>

Caffeic acid

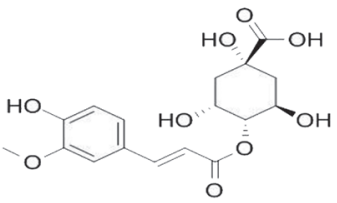

4-O-Feruloylquinic acid

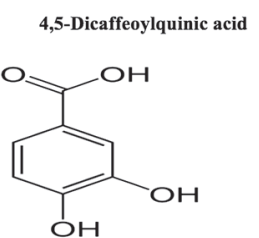

Protocatechuic acid

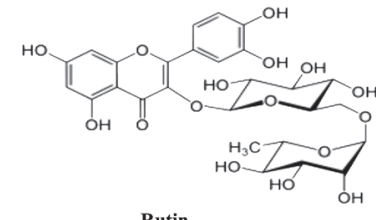

Rutin
Figure 2. Chemical structures of some phenolic compounds tentatively identified in hydroalcoholic extract of Artemisia campestris

a peak at $R_{t}=114.0$ showed a deprotonated ion $[\mathrm{M}-\mathrm{H}]^{-}$at $\mathrm{m} / \mathrm{z}$ 313 and characteristic $M^{n}$ ions at $\mathrm{m} / z 298$ due to the loss of methyl moiety $\left[\mathrm{M}-\mathrm{H}-\mathrm{CH}_{3}\right]^{-}$and 283 due to further loss of another methyl moiety $\left[\mathrm{M}-\mathrm{H}-2 \mathrm{CH}_{3}\right]^{-}$; it was identified as $4^{\prime}, 7^{\prime}$-dimethoxy luteolin. ${ }^{25}$

\section{Antioxidant activity and total phenolic content}

In the current study, the ORAC (Trolox equivalents, TE) value $(120.5 \pm 10.4 \mu \mathrm{mol}$ TEAC/g DW) was below the results (263.65 $\pm 39.7 \mu \mathrm{mol}$ TEAC/g DW) found by Bakchiche et al. ${ }^{7}$ and higher than the values of different Artemisia species harvested in Korea reported by Lee. ${ }^{26}$ This can be due to several reasons such as the method of extraction and the date and place of harvest (seasonal variations).

The reagent Folin-Ciocalteu is used in the quantification of total phenols; it is not only specific for phenols but also has the ability to reacts with sugar, protein, etc. For this reason our result was very high. We found a value greater than the values of the total phenols with the same species reported by Djeridane et al. ${ }^{27}$ (20.38 mg/g GAE DW) and Bakchiche et al. ${ }^{7}$ (53.84 mg/g GAE DW).
Bakchiche et al. ${ }^{7}$ previously stated that the hydroalcoholic extract from aerial parts of $A$. campestris possessed high antioxidant activity coupled to high phenolic content. Further investigation of known phenolic compounds in this extract, quantified by HPLC-MS/MS, revealed that chlorogenic acid was in high abundance $(161.92 \pm 5.4 \mathrm{mg} / \mathrm{g}$ DW) and was most likely responsible for the majority of the observed antioxidant activity. ${ }^{7}$ In the current study, $A$. campestris extract, which demonstrated high antioxidant activity and phenolic content, was further analyzed for the presence of a number of mono (3-O-cafleoylquinic, 5-O-caffeoylquinicacids) and di (3,4-dicaffeoylquinic acid, 4,5-dicaffeoylquinic acid) substituted chlorogenic acid derivatives using HPLC-MS/MS. Numerous previous reports revealed the antioxidant activity of medicinal plants based on the presence of certain polyphenolic compounds including phenolic acids, flavonoids, tannins, and their derivatives. ${ }^{28-30}$

\section{CONCLUSIONS}

The aim of the present study was to contribute to the identification of the major phenolic compounds in the hydroalcoholic extract of $A$. campestris; quantification of phenolic and flavonoid contents and hydroxycinnamic acid was carried out, and the antioxidant capacity of the extract was evaluated by ORAC assay. According to the data obtained, 11 phenolic compounds in the hydroalcoholic extract were tentatively identified using HPLCDAD-ESI-MS/MS. The identified compounds contained phenolic acid derivatives and flavonoids. Moreover, the hydroalcoholic extract showed a noticeable antioxidant potential; this high activity may be due to the presence of phenolic compounds. In conclusion, the aerial parts of $A$. campestris are considered a promising source of naturally occurring antioxidant agents, and its polyphenol profile may be regarded as a model for caffeoylquinic acid distribution in the plant $A$. campestris and can help to distinguish chlorogenic acid isomers.

Conflict of Interest: No conflict of interest was declared by the authors.

\section{REFERENCES}

1. Quézel P, Santa S. New flora of Algeria and the meridional desert regions (In French). Paris; CNRS;2013:2.

2. Abad MJ, Bedoya LM, Apaza L, Bermejo P. The Artemisia L. Genus: a review of bioactive essential oils. Molecules. 2012;17:2542-2566.

3. Dob T, Dahmane D, Berramdane T, Chelghoum C. Chemical compostion of the essential oil of Artemisia campestris L. from Algeria. Pharm Biol. 2005:43:512-514.

4. Akrout A, Gonzalez LA, El Jani H, Madrid PC. Antioxidant and antitumor activities of Artemisia campestris and Thymelaea hirsuta from southern Tunisia. Food Chem. Toxicol. 2011;49:342-349.

5. Djeridane A, Yousfi M, Nadjemi B, Vidal N, Lesgards JF, Stocker P. Screening of some Algerian medicinal plants for the phenolic compounds and their antioxidant activity. Eur Food Res Technol. 2007;224:801-809. 
6. Karabegovic I, Nikolova M, Velickovic D, Stojicevic S, Veljkovic, V, Lazic M. Comparison of antioxidant and antimicrobial activities of methanolic extracts of the Artemisia sp. recovered by different extraction techniques. Chin J Chem Eng. 2011;19:504-511.

7. Bakchiche B, Gherib A, Aazza, S, Gago C, Miguel MG. Antioxidant activities of eight Algerian plant extracts and two essential oils. Ind Crops Prod. 2013;46:85-96.

8. Megdiche-Ksouri W, Trabelsi N, Mkadmini K, Bourgoua S, Noumi A. Artemisia campestris phenolic compounds have antioxidant and antimicrobial activity. Ind Crops Prod. 2014;63:104-113.

9. Valant-Vetschera K, Fischer R, Wollenweber E. Exudate flavonoids in species of Artemisia (Asteraceae-Anthemideae): new results and chemosystematic interpretation. Biochem Syst Ecol. 2003;31:487-498.

10. Ferchichi L, Merza J, Landreau A, Ray AML, Legseir B, Seraphin D, Richomme P. Occurrence of isocoumarinic and phenolic derivatives in Artemisia campestris L. subsp. campestris. Biochem Syst Ecol. 2006;34:829-832.

11. Stamatakis G, Tsantila N, Samiotaki M, Panayotou GN, Dimopoulos AC, Halvadakis CP, Demopoulos CA, Detection and isolation of antiatherogenic and antioxidant substances present in olive mill wastes by a novel filtration system. J Agric Food Chem. 2009;57:10554-10564.

12. Huang D, Ou B, Hampsch WM, Flanagan JA, Prior RL. High throughput assay of oxygen radical absorbance capacity (ORAC) using amultichannel liquid handling system coupled with a microplate fluorescence reader in 96-well format. J Agric Food Chem. 2002;50:4437-4444.

13. Feliciano RP, Bravo MN, Pires MM, Serra AT, Duarte CM, Boas LV, Bronze MR. Phenolic Content and Antioxidant Activity of Moscatel Dessert Wines from the Setubal Region in Portugal. Food Analy Meth. 2009;2:149-161.

14. Mabry TJ, Markham KR, Thomas M. The Systematic Identification of Flavonoids. New York; Springer Verlag Publication; 1970;294:261-266.

15. Riedel H, Cai Z, Kutuk O, Smetanska I. Obtaining phenolic acids from cell cultures of various Artemisia species. Afric J Biotech. 2010;9:8805-8809.

16. Carvalho M, Silva BM, Silva R, Valentão P, Andrade PB, Bastos ML. First report on Cydonia oblonga Miller anticancer potential: Differential antiproliferative effect against human kidney and colon cancer cells. J Agric Food Chem. 2010;58:3366-3370.

17. Dagnon S, Ivanov I, Bojilov D, Docheva M, Statkova S. Evaluation of the Main Polyphenolic Compounds in Aromatic Plants of Asteraceae and Solanaceae Families of Bulgarian Origin. J Pharma and Phytoch. 2013:76-84.

18. Sebai H, Jabri MA, Souli A, Hosni K, Selmi S, Tounsi H, Tebourbi O, Boubaker S, El-Benna J, Sakly M. Protective effect of Artemisia campestris extract against aspirin-induced gastric lesions and oxidative stress in rat. RSC Adv. 2014;4:49831-49841.
19. Charrouf Z, Hilali M, Jauregui O, Soufiaoui M, Guillaume D. Separation and characterization of phenolic compounds in arganfruit pulp using liquid chromatography-negative electrospray ionization tandem mass spectroscopy. Food Chem. 2007;100:1398-1401.

20. Al-Rawahi AS, Edwards G, Al-Sibani M, Al-Thani G, Al-Harrasi AS, Rahman MS. Phenolic constituents of pomegranate peels (Punica granatum L.) cultivated in Oman. Euro J Med Plants. 2014;4:315-331.

21. Biesaga M, Pyrzynska K. Liquid chromatography/tandem mass spectrometry studies of the phenolic compounds in honey. J Chrom A. 2009;1216:6620-6626.

22. Ghareeb MA, Mohamed T, Saad AM, Refahy LA, Sobeh M, Wink M. HPLC-DAD-ESI-MS/MS analysis of fruits from Firmiana simplex (L.) and evaluation of their antioxidant and antigenotoxic properties. J Pharm Pharm. 2018;70:133-142.

23. Sobeh M, Hassan SA, El Raey MA, Khalil WA, Hassan MAE, Wink M. Polyphenolics from Albizia harveyi exhibit antioxidant activities and counteract oxidative damage and ultra-structural changes of cryopreserved bull semen. Mol. 2017;22:1993.

24. Abu-Reidah IM, Ali-Shtayeh MS, Jamous RM, David Arráez-Román D, Segura-Carretero A. HPLC-DAD-ESI-MS/MS screening of bioactive components from Rhus coriaria L. (Sumac) fruits. Food Chem. 2015;166:179-191.

25. Simirgiotis MJ, Benites J, Areche C, Sepúlveda B. Antioxidant capacities and analysis of phenolic compounds inthree endemic Nolana species by HPLC-PDA-ESI-MS. Mol. 2015;20:11490-11507.

26. Lee JH. Evaluation for Antioxidant Activity of Artemisia sp. Plants. Research J Med Plant. 2014;8:258-268.

27. Djeridane A, Yousfi M, Nadjemi B, Boutassouna D, Stocker P, Vidal N. Antioxidant activity of some Algerian medicinal plants extracts containing phenolic compounds. Food Chem. 2006;97:654-660.

28. Ghareeb M, Saad A, Ahmed W, Refahy L, Nasr S. HPLC DAD ESI MS/ MS characterization of bioactive secondary metabolites from Strelitzia nicolai leaf extracts and their antioxidant and anticancer activities in vitro. Pharmacogn Res. 2018;10:368-378.

29. Ghareeb MA, Sobeh M, Rezq S, El-Shazly AM, Mahmoud MF, Wink M. HPLC-ESI-MS/MS profiling of polyphenolics of a leaf extract from Alpinia zerumbet (Zingiberaceae) and its anti-Inflammatory, antinociceptive, and antipyretic activities in vivo. Molecules. 2018;23:3238.

30. Sobeh M, Mahmoud MF, Hasan RA, Abdelfattah MA, Sabry OM, Ghareeb MA, El-Shazly AM, Wink M. Tannin rich extracts from Lannea stuhlmannii and Lannea humilis (Anacardiaceae) exhibit hepatoprotective activities in vivo via enhancement of the anti apoptotic protein bcl 2. Sci Rep. 2018;8:9343. 